\title{
"Al hjerne er ikke i ét hoved, al viden ej hos én"
}

af Gert Posselt

\section{Overblik og sammenhænge}

er begreber, der mod slutningen af 1900-tallet er kommet i høj kurs. De føles som mangelvarer. Vidensmængder, der hastigt vokser, og massemedier, der konstant pumper informationer i hovedet på befolkningen, er trusler mod det overblik, der prøver på at modstå primitive forenklinger. Sådan et samfund lever vi i, på godt og ondt. Intet nulevende menneske i det, vi plejer at kalde vores del af verden, har levet under vilkår, der var væsentligt anderledes end disse.

At levere et overblik over almene, aktuelle facts inden for alle dele af menneskelig viden - og et overblik over sammenhængene - er det ideal, som de encyklopædiske opslagsværker prøver at virkeliggøre.

Idealet var nemmere at føre ud i livet dengang, da mennesket i sin søgen efter erkendelse endnu ikke var kommet så langt i opsplitningen af verdens bestanddele, som vi er i dag. Det er naturligvis en væsentlig grund til, at man lettere kunnebevareoverblikket dengang. Det er blevet besværligere for vor generation - samtidig med, at det føles nødvendigt at prioritere den viden, som ingen enkeltperson kan overskue.

\section{Encyklopædi}

betyder noget i retning af oplæren i at bevæge sig rundt i nødvendige kundskaber. Ordet er sammensat af kyklos, kreds, og paideia, undervisning. Det er betegnelsen for et bogværk, der viser rundt i almendannelsens bestanddele og sammenhænge. 
Leksikon betyder en ordbog, der indeholder alfabetisk ordnede stikord.

Encyklopædi og Leksikon er græske kunstord, dvs. at de er konstruerede længe efter den klassiske oldtid. Sådan som de to begreber bruges i dag, er det vanskeligt at afgrænse dem klart fra hinanden.

Ambitionen om at samle et overblik over den oplyste borgers nødvendige viden opstod hos grækerne og blev realiseret adskillige gange i den romerske oldtid, f.eks. i Plinius den Ældres store Naturhistorie fra o. 70 e.Kr. De var næsten alle systematisk opbyggede. Fagene (geografi, astronomi, mineralogi, medicin, zoologi, botanik, m.m.) var overordnede temaer, hvorunder enkeltbegreber kunne søges i deres indbyrdes sammenhæng. Sådan et omfattende værk erstattede i praksis mange enkelt-bøger. Den systematiske indretning var enerådende middelalderen igennem og holdt sig frem til o. 1700. Herefter blev et systematisk enhedspræg opgivet. Det levede herefter videre i form af enkeltfagenes fagterminologiske opslagsbøger.

Allerede i 1600-tallet havde den voksende viden på mange områder gjort en alfabetisk indretning nødvendig til afløsning af den systematiske. Det var stadig eliten, der anvendte sådanne værker, men også den var under gradvis forandring. Den intellektuelle elite voksede i løbet af disse århundreder, og det var ikke længere en selvfølge, at den bekræftede magthavernes syn på verden.

En banebryder for skepticismen var den franske filosof Pierre Bayle. I 1696-97 udkom hans Dictionnaire historique et critique (Historisk og kritisk leksikon) i Rotterdam. Stilen var ny: korte og klare artikler med udførlige, personligt ræsonnerende noter til forskel fra alenlange, ukritiske citatsamlinger, som foregående værker kunne være fulde af. Bayle argumenterede for fuld religionsfrihed og stillede spørgsmålstegn ved værdien af den menneskelige fornuft. Fornuften kan nok vinde magten, - og det er godt, men den kan aldrig beholde magten, fordi fornuften altid fører til tvivl, - og fordi den intet kan stille op over for det ondes realitet $i$ verden.

Bayles leksikon betragtes som en indledning til oplysningstiden. Det var kontroversielt. Det kom i flere udgaver og fik en kolossal betydning, der herhjemme kan aflæses flere steder i Ludvig Holbergs historisk-filosofiske forfatterskab.

Mange, især tyske værker så dagens lys i 1700-tallets første halvdel. 
Det var universal-encyklopædiernes storhedstid. Ambitionen om så fuldstændige beskrivelser af alting som muligt levede i bedste velgående.

Det universelle indhold er encyklopædi-genrens fornemste kendetegn. Det er et kendetegn, der passede til oplysningstidens dannelsesideal: Samfundsborgeren bør kunne tale kyndigt om alt, uden at det bærer præg af fag.

\section{Oplysningstiden}

er den almindelige betegnelse for den periode i europæisk åndsliv, der rækker fra årene o. 1700 til den franske revolution 1789. Enhver form for autoritetstro blev draget i tvivl. Fornuften var ledetråd i erkendelsen af naturen, - skepsisen en ekstra drivkraft. Oplysning var vejen til fremskridt, og religionen fik intellektuelt modspil i såvel protestantiske som katolske lande. Disse mange radikale nyvurderinger skulle formuleres, og leksikonmediet var gennem hele 1700-tallet en velegnet og yndet form.

Det berømteste af dem alle - et hulspejl af hele tidsalderen - er Den store franske encyklopædi. Encyclopedie ou Dictionnaire raisonné des sciences, desarts et des métiers, (Encyklopædi eller Analytisk ordbog for videnskaberne, kunstarterneog professionerne) 35bind (24 bind tekst og 11 bind kobberstukne plancher) udkom mellem 1751 og 1780.

Bayle havde vist, at et leksikon kan bruges til virkningsfuld samfundskritik, og den erfaring tog det næste slægtled til sig. Diderot og d'Alembert redigerede det stort anlagte værk. De kom hurtigt i karambolage med den franske censur og i 1759 (da bind 7 var udsendt) med Pavestolen, der satte Encyklopædien på index over forbudte bøger. Forlæggeren satte fingeredeudenlandske trykkesteder på de følgendebind, og flere kontroversielle afsnit strøg han i manuskriptet uden Diderots vidende. Værket fik godt og vel 4200 subskribenter og blev alt ialt en god forretning. Blandt de knap 200 skrivende medarbejdere var lysende navne som Rousseau (musik), Montesquieu (artiklen "goût", smag) og Voltaire. Værd at bemærke er også den udførlige behandling, som alle former for teknik og håndværk fik, i beskrivende tekst og i over 3000 illustrationer.

Encyclopædia Britannica blev første gang udgivet i 1768-71 af "A Society of Gentlemen in Scotland". Det var en beskeden 3-binds udgave, men 


\section{ENCYCLOPEDIE,}

$\mathrm{O} \mathrm{U}$

\section{DICTIONNAIRE RAISONNE DES SCIENCES,}

DES ARTS ET DES METIERS,

PAR UNE SOCIETÉ DE GENS DE LETTRES.

Mis en ordre \& publié par M. DIDEROT, de l'Académie Royale des Sciences \& des BellesLettres de Prufie; \& quant à la Partie Mathé matique, par M. D’ ALEMBERT, de l'Académie Royale des Sciences de Paris, de celle de Pruffe, \& de la Société Royale de Londres.

Tantùm feries juncturaque pollet,

Tantùm de medio fumptis accedit honoris! HoRAT.

\section{TOME PREMIER.}

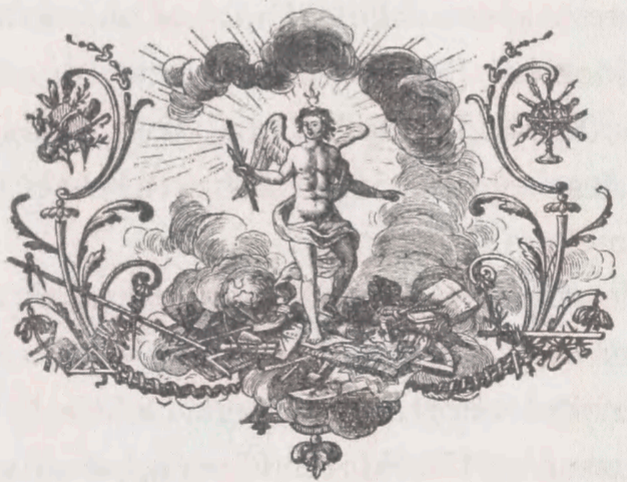

A P A R I S,

Chez $\left\{\begin{array}{l}\text { B R I A S S O N, rue Saint Jacques, ḋ la Science. } \\ \text { D A V I D l'ainé, rue Saint Jacques, d la Plume d'or. } \\ \text { L E B R E T O N, Imprimeur ordinaire du Roy, nue de la Harpe. } \\ \text { D U R A N D, ne Saint Jacques, a Saint Landry, É au Griffor. }\end{array}\right.$

M. D C C. L I.

AVEC APPROBATION ET PRIVILEGE DU ROY.

Encyclopédie, ou dictionnaire raisonné des sciences, des arts et des métiers, par une societé de gens de lettres. I dette selskab af skribenter var bl.a. Rousseau, Voltaire og Montesquieu, og værket er et monument over oplysningstiden. Det udkom 1751-80 og bestod af ialt 35 bind. Her første binds titelblad. 
allerede i 3. udgaven (15 bind, 1788-97) lå kimen til den høje standard, der forlængst har gjort dette værk til et begreb over hele kloden. Det indeholdt artikler af vidt forskellig længde, den største var "Surgery" (kirurgi) på 238 sider. Senere udgaver er delt i to rækker: Macropædia med lutter store oversigtsartikler og Micropædia med almindelige leksikonartikler, personnavne, enkeltbegreber m.v. I 1899 kom Encyclopædia Britannica på amerikanske hænder, og siden 1943 er udgivelserne forestået af University of Chicago. I tidens løb har mange udenlandske medarbejdere leveret artikler til de àjourførte udgaver. Det er særligt fascinerende at stå over for den kombinerede 11.-12. udgave, 1910-22 ; heri findes bidrag skrevet af et par af århundredets mest indflydelsesrige skikkelser, Einstein og Freud, samt f.eks. Niels Bohr ("Atom"), Otto Jespersen ("Grammar"; "Philology"). Artiklen "Denmark" er skrevet af Erik Arup.

Den seneste 15. udgave af Encyclopædia Britannica udkom 1974-87 i 32 bind, og hvert år siden da er et nyt revideret oplag udsendt. Den løbende opdatering er dog noget ujævn; nogle fagområder er àjour, mens andre 'hænger' oplag efter oplag. Værkets kundekreds er verdensomspændende.

\section{0-tallet}

har bidraget med det største antal bind. En udgivelse med eksorbitant vokseværk var den "ökonomisch-technologische" encyklopædi, som Johann Georg Krünitz grundlagde i Berlin i 1773, og som hen ad vejen voksende med adskillige andre fag; i 1858 udkom bind 242! - Ersch \& Gruber's Allgemeine Encyclopädie der Wissenschaften und Künste kom i 1818-89 i 167 bind - og nåede endda kun til $\mathrm{Ph}$ i alfabetet. Ambitionen var intet mindre end udtømmende beskrivelser af alle emner! Medarbejderne var datidens mest fremragende tyske videnskabsmænd. Artiklen "Griechenland" fylder 4 bind, mens "Dänemark" dog kan rummes (udtømmende?) i 26 spalter. Udgivelsen overgik i 1831 til forlaget Brockhaus, der selv i 1796 havde påbegyndt det første egentlige konversationsleksikon. Det var af typen real-encyklopædi, altså talrige stikordsindgange og artikler af forholdsvis lille gennemsnitslængde, i modsætning til den universelle type encyklopædi, der rummer store oversigtsartikler. Til gengæld vandt Brockhaus og utallige andre konversationsleksika sidenhen en meget stor udbredelse i snart sagt allelag af befolkningen. 
Ligesom Encyclopædia Britannica kommer Brockhaus stadig i nye udgaver.

Meyer er ligeledes et endnu levende begreb. Meyers Grosse Conversations-Lexicon für die gebildeten Stände udkom første gang i 46 bind, 1840-55. - Brockhaus og Meyer er detyske begreber, der svarer til Salmonsen og til Larousse (Le Grand Dictionnaire universel du XIXe siècle, første udgave i 15 bind, 186676).

For flere generationer i Sverige var Nordisk familjebok. Konversationslexikon och realencyklopedi et begreb. Den udkom første gang i 18 bind, 1874-94, og siden i endnu to udgaver frem til 1920'erne. I førsteudgaven var artiklen "Djäfvul", Djævel, kompetent skrevet af den unge forfatter Au-gust Strindberg, nogenlunde samtidig med, at romanen Röda rummet blev udgivet i 1879. De 113 linjer spænder over en historisk karakteristik af den Ondes person, lige fra hans mange forskellige navne i de gamle kulturer over senere tiders hekseprocesser til jætter og trolde i europæiske folkeeventyr. Man mærker nok, at det er en forfatter, der har stor viden om - og sans for - det dæmoniske.

\section{Danmark}

var det første store leksikon overlærer H. A. Kofod:Conversations-Lexikoneller encyklopædisk Haandbog, der udkom i 1816-28 i 28 bind. Det var en oversættelse af Brockhaus, men Kofod havde bearbejdet den selvstændigt, så den bedre opfyldte danske behov.

Forud havde pastor Frølund før ca. 1750 oversat Bayles Dictionnaire til dansk, intervallet A til Glei, og endnu tidligere havde Matthias Moth anlagt en stor selvstændig ordbog, men begge forblev utrykte (manuskripterne findes på Det kongelige Bibliotek).

Salmonsens store illustrerede Konversationsleksikon kom i 19 bind, 18931911. De oprindelige planer gik ud på at udgive en dansk oversættelse af Meyers Lexikon, men det endte med et helt nyt dansk leksikon med godt 700 fagfolk som medarbejdere. Langt de fleste heraf var danske, men også en del nordmænd og nogle svenskere har leveret artikler. For eftertiden er især de store artikler om de allernyeste tekniske opfindelser som f.eks. Luftsejlads (dvs. flyvning) og Vandkloset af (teknik- og kultur)historisk interesse. Også de usædvanligt grundige militærhistoriske artikler springer i øjnene; det 
Lomme encyclopedie for Børn. Den lille Naturven, en Nytaarsgave for videlystne Børn. Bd. 1-6, 1809-14.

Alle bindene er illustrerede med håndkolorerede kobberstik.

Alt det virkelig drejer sig omen 'lommeencyclopedie' fremgår af, at bindene måler $8,8 \times 5,5 \mathrm{~cm}$.
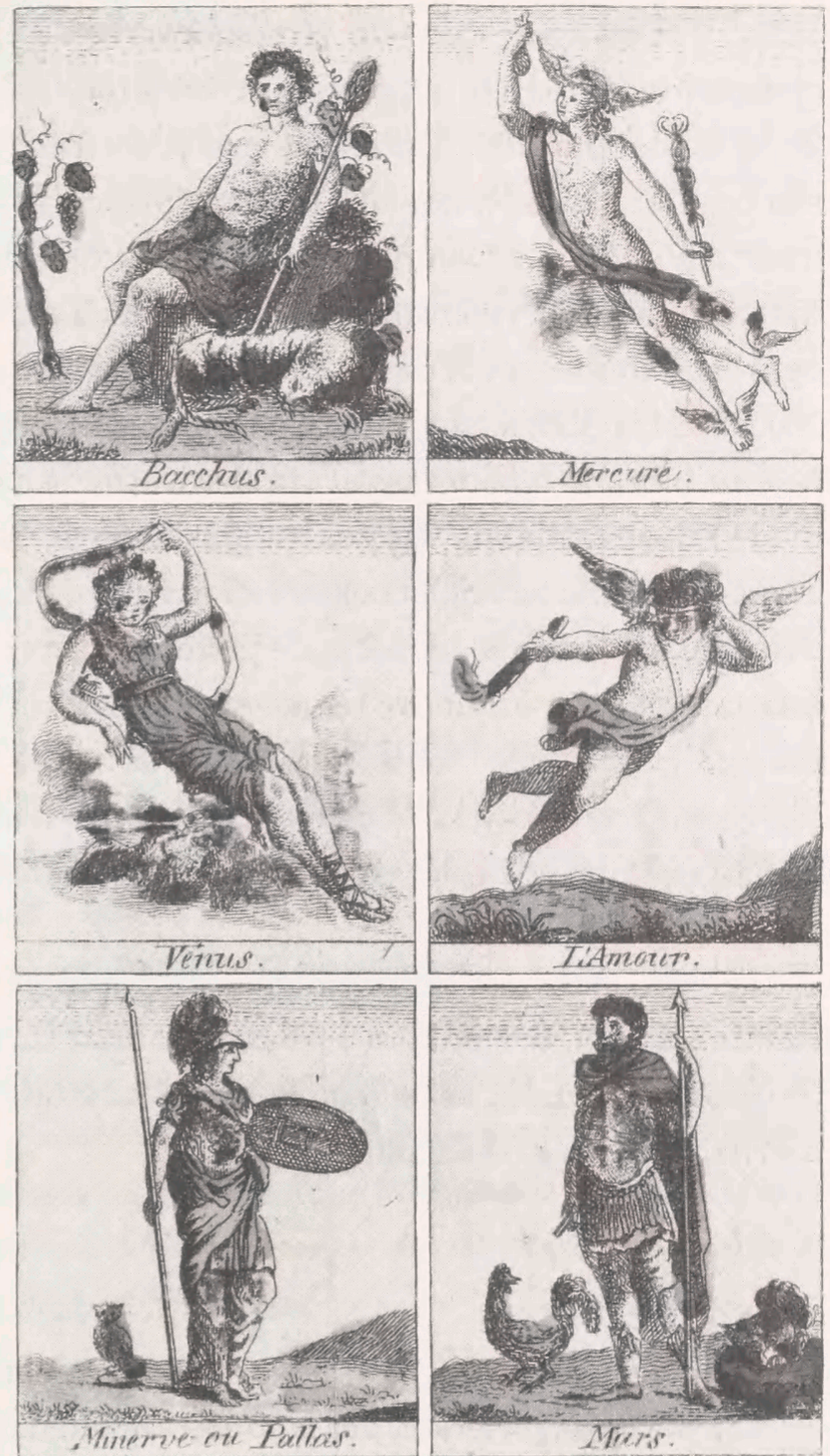

store antal af sidstnævnte har utvivlsomt sammenhæng med, at redaktør Blangstrup var kaptajn i hæren ...

Anden-udgaven fylder 26 bind og udkom over en periode med store forandringer i verdens historie: 1915 til 1930, i et oplag på ca. 30.000 eksemplarer.

Siden da er der herhjemme udsendt mange forskellige leksika, lige fra Den Lille Salmonsen i 12 bind, 1937-40, til Lademanns leksikon i 20 bind, 1970-78 og i 32 bind, 1982-89. 
Det igangværende redaktionsarbejde til Den Store Danske Encyklopædi leder frem til udgivelsen af første bind i slutningen af $1994 \mathrm{og}$ af det 20. og sidste bind i 2001. Det er Gyldendal, der med fondsstøtte og statsgaranti står bag Danmarks Nationalleksikon A/Sog dermed bag projektet, der er det mest omfattende i Danmark siden Salmonsen. Førende danske forskere inden for samtlige vidensfelter vil bidrage med artikler, og det bliver dermed også et monument over dansk videnskabsformidlings stade $i$ årene omkring 2000. Værket planlægges tillige i en elektronisk udgave, der rummer mulighed for løbende opdatering af artiklerne. Denne udgave vil ikke på samme måde kunne fastholde vor generations aktuelle synspunkter på verden for eftertiden, fordi indholdet - og det vil navnlig gælde de naturvidenskabelige dele samt naturligvis den løbende politiske historie - til stadighed vil kunne forandres. Det 20. århundredes massemedier giver lynhurtige svar og passer dermed godt til den side af nutiden, hvor nøgne data og hurtighed er det vigtigste. Overblik og sammenhænge kræver lidt mere tid. Som massemedie har bogen sine fortrin, der givetvis også i det 21. århundrede vil kunne hævde sig.

Projektet kan sammenlignes med Aschehoug og Gyldendals Store Norske Leksikon, der udkom 1978-81 i 12 bind (2. udgave 1986-89) og med Nationalencyklopedin, der siden 1989 er under udgivelse iSverige, og som den danske er planlagt til 20 bind.

\section{Specialleksika}

er en helt anden genre. Den udspringer som nævnt af de universelle systematiske opslagsværker, der fandtes i antikken og som endnu i 1600-tallet blev fremstillet i Europa. Sådanne alfabetisk ordnede realleksika findes der utallige af inden for alle fag, lige fra almenfattelige udgaver som den tyske billigbogsserie Fischer Lexikon, hvor hvert bind dækker et fag eller en disciplin, til højt specialiserede opslagsværker, svært tilgængelige for andre end fagfolk.

Personalhistorie er i Danmark fornemt dækket af Dansk Biografisk Leksikon, hvis 3. og seneste udgave, 16 bind, udkom 1979-84. Kraks Blå Bog udkommer årligt med kendte nulevende danskeres levnedsløb, svarende til udenlandske årbøger som Who's Who?, Vemärdet? m.v. En klassiker inden for 
et mere afgrænset felt er Weilbachs Kunstnerleksikon, hvor en ny udgave her i 1990'erne er ved at være på trapperne.

Så at sige alt, hvad der er værd at vide om den antikke verden, kan slås op i den gigantiske Pauly's Real-Encyclopädie der classischen Altertumswissenschaft, der fylder henved 80 bind, udgivet (i 2. udgave v/Georg Wissowa m.fl.) fra $1894 \mathrm{og}$ fremefter. En fortrinlig billigbogsudgave findes i 5 indholdsrige bind: Der Kleine Pauly. Lexikon der Antike, München 1979. Et fællesnordisk værk dækker en anden historisk periode i de nordiske lande: Kulturhistorisk Leksikon for Nordisk Middelalder, der udkom i 22 bind, 1956-78.

Alle tænkelige emner i menneskets erkendbare verden er dækket af alfabetiske opslagsbøger, lige fra oldgamle fænomener til det nyeste nye. Et fremragende eksempel på det sidste kan f.eks. være EDB-LEX. Det store informatik-leksikon (Teknisk Forlag, 1991).

Mange opslagsbøger i Danmark har navn efter det forlag, der udgiver dem: Gads Musikleksikon, Gyldendals Tegneserieleksikon osv. Især Politikens Forlag har i flere årtier været flittig udgiver af specialleksika: Politikens Jazz-, Dansk Rock-, Filosofi-, Bibel-, Religions- med-mange-flere- leksikon, foruden genren "Hvem skrev hvad?", "Tegneseriernes hvem-hvad-hvor" o.lign. Ikke alle er disponeret som et alfabetisk sammenhængende opslagsværk. Politikens Okkulte Leksikon, der også hedder Mystikkens verden, er f.eks. ordnet i tematiske afsnit, indenfor hvilke centrale begreber står beskrevet $\mathrm{i}$ alfabetisk rækkefølge. Feltet er meget righoldigt i Danmark. Internationalt er det uoverskueligt. Den simple forklaring er, at det er en praktisk måde at systematisere og tilgængeliggøre viden på.

\section{Paratviden}

er et begreb, som vor tid ikke tillægger megen betydning i forbindelse med f.eks. den opvoksende generations skolegang. Kriterierne for udvælgelse af den almene viden er ikke længere entydige, og op-lysning kan være mange ting. Alligevel føler mange, der er borgere i et af jordens mest informationsmættede og oplyste samfund, et behov for at tilegne sig både gammel og ny viden og række den videre. De nordiske encyklopædiprojekter i 198090 'erne udspringer bl.a. af dette behov for at formulere det væsentlige i forhold til flimmeret. 
"Al hjerne er ikke i ét hoved, al viden ej hos én", står der i Peder Syvs ordsprogssamlinger fra 1600-tallets slutning. At vide hvor man skal gå hen for at få svar, det er stadig dét, det drejer sig om. I bogform står der altid viden parat, både af den eksakte slags og af den mindre eksakte, som rummer længst henfarne slægters erfaringer og tolkninger af livet og alt hvad dertil hører,- parat til at føre dialog med os nulevende om alt det, der interesserer os.

Et stort, gedigent leksikon kan besvare hundredtusindvis af spørgsmål. Det kongelige Biblioteks righoldige samlinger rummer svar på uendelig mange spørgsmål, også af den slags, der slet ikke er stillet endnu. Et sådant arsenal er en åndelig livsbetingelse for ethvert samfund. Den 200-årige adgang til at søge oplysning har vi alle i Danmark ære - og gavn! - af at kunne markere.

André Nicolet: Encyklopædier og Konversationslexica gennem Tiderne, Kbh, 1946.

Axel Andersen (red.): Danskeopslagsværker, bd. 1-2. G.E.C.Gad, Kbh, 1977.
Axel Andersen: Håndbøgernes håndbog. 3. rev. udgave. Forlaget Sesam, 1979. 